\title{
THE IMPORTANCE OF UNDERSTANDING CULTURAL AWARENESS FOR MANAGERS IN THE HOSPITALITY INDUSTRY (IN INDONESIA)
}

\author{
Hera Oktadiana $^{1}$; Rendy Herindra Djauhari ${ }^{2}$ \\ 1,2 Jurusan Hotel Manajemen, Fakultas Ekonomi dan Bisnis, Bina Nusantara University \\ Jln. K.H. Syahdan No. 9, Kemanggisan, Palmerah, Jakarta Barat 11480
}

\begin{abstract}
Cultural awareness is a basic knowledge that each individuality must has. In hotel industry, there are positive advantages that could be reached if a manager could appreciate a cultural, value, attitude differences of each person. This paper adjusts how important the understanding of cultural diversity and pragmatic implementation from several cross cultural communication theory, especially for managers in hotel industry. This paper also describes examples of cultural attitude and habits from some countries that could be refferences in workforce diversity.
\end{abstract}

Keywords: intercultural communication, cultural awareness, workforce diversity

\begin{abstract}
ABSTRAK
Peka terhadap budaya merupakan sebuah modal yang harus dimiliki oleh setiap individu. Di Industri perhotelan banyak sekali keuntungan positif yang dapat dicapai apabila seorang manajer bisa saling menghargai adanya perbedaan budaya, nilai, sikap dan perilaku seseorang. Tulisan ini menekankan pada pentingnya pemahaman keragaman budaya dan implementasi pragmatik dari beberapa teori komunikasi lintas budaya, khususnya bagi manajer di industri perhotelan. Tulisan ini juga menjabarkan beberapa contoh perilaku dan juga kebiasaan budaya dari beberapa negara yang dapat dijadikan referensi dalam proses kerja yang multikultural.
\end{abstract}

Kata kunci: komunikasi antarbudaya, peka terhadap budaya, proses kerja multikultural 


\section{INTRODUCTION}

The hospitality industry, which includes lodging properties and food and beverage operations, is a segment within the tourism industry. There are four major segments in the tourism industry; hospitality, retail stores, transportation and destination (activities) sites. As a service industry, the hospitality industry has attributes that distinguish itself from the manufacturing industry. They are intangibility (the difficulty to measure, describe or standardize), simultaneity (service is produced and consumed in the same place and almost at the same time), perishability (service cannot be stored for future sales; the potential income from an unsold room is lost forever), heterogeneity (the quality of service is defined by each customer), and inseparability (services are inseparable from their providers, thus their quality depends on the providers).

The hospitality industry is growing rapidly worldwide and is becoming one of the largest industries in the world. This industry has some distinctive characteristics. It is service orientated in which the intangibility of services and the tangibility of products are combined and labor-intensive. This industry offers the best employment and business opportunities and is becoming the largest provider of employment opportunities in this century.

Considering those factors, today's hotel managers must understand the importance of multicultural concepts and communication skills in order to be able to work in a workforce diverse environment. In general, there are some benefits that can be gained from understanding the different cultures for the hospitality business. It improves good relations between staff in the workplace and overcomes anti-discrimination. When staff are happy and can work in harmony, they are able to provide better service to guests in order to ensure the guests' satisfaction.

Therefore, hotel managers must have capability to communicate and deal effectively with people from different cultures, as they are tasked with the responsibility of ensuring that communication between colleagues, staff, clients and customers is clear, coherent and free from intercultural misunderstandings. In order to achieve this, they must possess certain key attributes. These are namely, intercultural awareness, flexibility, and capitalizing on differences.

\section{Intercultural Communication Competency}

Intercultural communication is defined as 'involving interpersonal communication between people from different socio-cultural systems and/or communication between members of different subsystems (e.g., ethnic or racial groups) within the same socio cultural system' (Gudykunst, 1987). Communication competence is conceptualised as an individual's ability to adapt effectively to the surrounding environment over time (Spitzberg \& Cupach, 1984). The central feature of this definition is the focus on adaptability, which has been widely accepted as a component of communication competence. Thus, in a culturally diverse workplace, competence in intercultural communication can be described as an ability to be flexible and adaptable to different cultural contexts, that is, sensitive to the cultural situation and acting accordingly.

Present indications suggest that the hospitality industry, as a service industry, has begun to recognize the value of improved communication as a key to establishing and increasing quality, productivity, and competitiveness. In the study of the hospitality industry for the 21st century, Powers \& Riegel (1993) conclude that the hospitality industry is very much a people business in which staff make all the difference in the customer experience. Brownel (1991) indicates that the managers in hospitality organizations must have the expertise to establish appropriate systems to communicate appropriately with employees at all levels. Studies of leadership in the lodging and food service sectors found that effective leadership includes the ability to listen and communicate effectively (Cichy, Sciarini, \& Patton, 1992). 
Problems that affect managers' competence in intercultural communication may result from any if the following: incorrect cultural assumption; stereotyping; ethnocentrism and insensitivity to other cultures' prejudice and discrimination; fear, misunderstanding of roles; different values; different roles, and inaccurate interpretation of behavior. In addition, problems in intercultural based communication can arise due to a mismatch between the values of a corporate culture and its culturally diverse workforce.

Culture is highly pervasive: one's perceptions, attitudes, personality. Motivations, values, and learning experiences are to a large extent shaped by one's culture. Samovar \& Porter (1995) argue that culture governs and defines the conditions and circumstances under which various messages may or may not be sent, noticed, or interpreted. Our repertoire of communicative behaviors depends largely on the culture in which we have been raised. How people communicate is influenced by how they live, according to their culture. How people talk, what they talk about, and to whom are issues both of communication and culture. Hall \& Hall (1987) has consistently maintained that there is an inextricable relationship between culture and communication, arguing that any culture is primarily a system for creating, sending, storing, and processing information. Communication underlies everything. An ability to understand and respond to these communication differences is fundamental for competent managerial practice in hospitality workplaces.

The hospitality industry's power and its potential to maximize productivity depends on the effective management of multicultural human resources. Because the industry is labor intensive and centered on service, it is a people enterprise and thus rich in communication. However, there is a range of management problem in the Indonesian hospitality industry, including poor management skills relating to communication, staff motivation, and feedback to staff. Also, in Indonesia managing communication processes is sometimes portrayed as being complicated by the existence of a variety of competency in English and in languages other than English.

Managers need to understand how ethnicity and culture affect human behavior in general and how to communicate across cultures. Examples of workplace situations where culture can influence both management and a multicultural workforce include recruitment policies and procedures, such as interviewing, disciplinary actions and rules of conducts: dress codes' perceptions of times; service procedures; the motivation for professional development' employee counseling; work schemes; and the role of women. Effective communication is required a culturally diverse workforce in order to perform effective major managerial functions, such as planning, organizing, coordinating, leading, motivating staff, and dealing with industrial relations.

\section{Theoritical Perspectives}

For intercultural communication to be successful, participants need to know something about each other's cultures. Hall (1979) divides the cultures of the world into high context (group-oriented) and low-context (individualistic), and suggests that context influences interpersonal communication. Communication in high-context cultures depends less upon the words than the context and the opposite occurs in low-context cultures. Thus, an understanding of the context in communication is crucial in high-context cultures.

A more empirically based analysis of world cultures is the cultural dimensions model, developed by Hoftsede (1995) who undertook a comprehensive study of worldwide social-cultural factors influencing management. From his survey of 116,000 employees in 40 countries, he isolated four major dimensions congruent with the different cultural values of these countries: (1) individualism-collectivism dimension refers to the extent that people in a society define themselves as autonomous individuals or through their memberships in groups; (2) in the power distance dimension, high power distance is characterized by top-down decision making, loyalty to the boss, and rigid hierarchical structures. Low power distance translates into egalitarian work environments, flexible 
hierarchies, and participative management; (3) for the femininity-masculinity dimension, masculine values include productivity, competition, monetary gain, and status; and feminine values include quality of life, societal welfare, and cooperation; (4) for the uncertainty avoidance dimension, high uncertainty avoidance leads to explicit (written) rules and regulations, and hence reliance on information systems, and low uncertainty translates into few formalized rules.

Hofstede \& Bond (1984) later identified a further cultural dimension, Confucianism dynamism, which concern long-term versus short-term orientation. According to Hofstede (1995), values associated with ling term orientation are thrift and perseverance, values associated with short term orientation are respect for tradition fulfilling social obligations, and protecting one's face.

The elements of the cultural dimensions model suggest that considerable sensitivity, adaptability, and empathy is required to negotiate intercultural encounters. It is still questionable whether the hospitality managers in Indonesia have or have not understood these conceptual frameworks and/or the issues involved. Psychological theories of intercultural communication have emphasizes individual variables that determine stages of adaptation or acculturation to a dominant culture. Three theories are drawn upon for this paper: systems, anxiety/uncertainty reduction, and convergence.

In the systems-theoretic view (Kim \& Reuben 1988), individuals are considered systems that function through ongoing interaction with the environment and its inhabitants. Cultural strangers can develop intercultural communication competence in a four stage process: the culture shock of entering unfamiliar environments; stress from this shock; adaptation through finding ways of coping or reducing stress' and growth, when they cultivate increasing degrees of intercultural communication competence.

Closely related to a system approaches in the psychological theory of anxiety/uncertainty reduction (Gudykunst, 1987). The theory is based on the principle that interpersonal communication is enhanced under conditions of reduced anxiety/uncertainty. Another influential psychological theoretical perspective is convergence theory (Kincaid, 1988), which suggests that individuals who share information will, over time, tend to converge toward one another, and thus become more uniform.

\section{DISCUSSION}

\section{The Intercultural Managers}

The role of a manager is evolving in response to the needs of companies operating on the international stage. The complexities of globalization brought to the area of management are great and require the 21st century manager to adapt in order to offer modern solutions to modern problems. One area in particular of growing importance is intercultural management skills. The majority of companies can no longer escape the need to buy, sell or work with people from different cultures. Multinationals have offices spanning the globe; manufacturers increasingly rely on foreign markets and distributors; services and products are no longer solely marketed at native audiences and many industries rely on immigrant labor. In short, very few businesses escape the need for intercultural communication.

As a result, companies are increasingly recognizing that in order to grow, diversify and retain a competitive advantage, intercultural management skills are critical. Intercultural management skills is a loose term used to refer to the capability of a manager to communicate and deal effectively with people from different cultures. Communication has long been recognized as the key to business success; however, intercultural communication is now an increasingly critical term. Intercultural 
communication is critical to business performance in a variety of ways. Internally, an intercultural manager needs to be able to act as a medium between senior personnel and staff; communicate clearly and effectively with colleagues; build and nurture efficient intercultural and transnational teams and display strategic global thinking.

Externally, an intercultural manager must demonstrate business acumen within a framework of intercultural awareness to supervise entrance into foreign markets; oversee the proper selection, mentoring and guidance of company representatives working with foreign interests; negotiate and manage conflict with clients and provide insight into potential areas of success or failure emanating from intercultural differences.

Once intercultural awareness is active within a manager and they are able to see beyond surface level manifestations of cultural differences, flexibility naturally occurs. Flexibility refers to the ability of the manager to adapt their behavior and management style to deal effectively with intercultural challenges and to think out of the box when it comes to offering solutions. The flexible intercultural manager is able to cushion intercultural tests and control outcomes positively. Similarly, the intercultural manager needs to be astute in using intercultural differences positively. Cross cultural differences do not inherently lead to negative consequences. They only do so when mismanaged. It is therefore the responsibility of the intercultural manager to assess the potential of personnel, products and policies being steered by cultural differences and ensuring it does so for a constructive outcome.

Finally, the intercultural manager needs patience. As the Dutch proverb says, "A handful of patience is worth more than a bushel of brains.” Patience is the key to a successful intercultural manager as it allows one to maintain focus, analyze problems coherently, evaluate options and implement solutions. The success of businesses in today's globalize world economy relies heavily upon them investing in cultivating intercultural managers. With human traffic across borders constantly on the increase and business interests dependent on foreign markets, the intercultural manager is critical to the co-ordination, supervision and implementation of clear intercultural communication.

\section{Intercultural Team-Building}

Internal business structures have been radically transformed over the past few decades. Changes in areas such as communication and transportation technology and shifts towards global interdependency have resulted in hotels and leisure industry becoming increasingly international and therefore intercultural. In addition, the need to 'go global' and to cut outgoings is demanding that companies combine protecting international interests whilst keeping down staff numbers. The solution in most cases has been the forming of intercultural teams.

As with all businesses, success depends upon effective cooperation and communication within teams. The intercultural dimension of today's teams however brings with it new challenges. Successful team building not only involves the traditional needs to harmonize personalities but also languages, cultures, ways of thinking, behaviors and motivations. Intercultural teams have an inherent disadvantage. Cultural differences can lead to communication problems, unpredictability, low team cohesion, mistrust, stress and eventually poor results. However, intercultural teams can in fact be very positive entities, such as in the areas of problem solving and creativity. The combination of different perspectives, views and opinions can lead to an enhanced quality of analysis and decision making while team members develop new skills in global awareness and intercultural communication.

In reality this best case scenario is seldom witnessed. More often than not, intercultural teams do not fulfill their potential. The root cause for this is that when intercultural teams are formed, people with different frameworks of understanding are brought together and expected to naturally gel. Without a common framework of understanding, for example in matters such as status, decision 
making, communication etiquette, this is very difficult and thus necessitates outside help to commix the team. Intercultural or cross cultural training is one method of helping to blend a team together. Through analysis of the cultures involved in a team, their particular approaches to communication and business and how the team interacts, intercultural team builders are able to find, suggest and use common ground to assist team members in building harmonious relationships. Intercultural training sessions look at helping a team to realize their differences and similarities in areas such as status, hierarchy, decision making, conflict resolution, showing emotion and relationship building. These are then used to create mutually agreed upon structures of communication and interaction. From this basis, teams are then tutored how to recognize future communication difficulties and their cultural roots, empowering the team to become more self reliant. The end result is a more cohesive and productive team.

For intercultural teams to succeed, managers and HR personnel need to be attuned to the need for intercultural training to help cultivate harmonious relationships. Companies must be supportive, proactive and innovative if they wish to reap the potential benefits intercultural teams can offer. This goes beyond financing and creating technological links to bring together intercultural teams at surface level and going back to basics by fostering better interpersonal communication. If international businesses are to grow and prosper in this ever contracting world, intercultural synergy must be a priority

\section{Leading and Motivating People from Different Cultures}

In the globalization business, the workforce transfers between countries are becoming increasingly common, especially in the dynamic environment of hospitality industry. Managers and executives in the hospitality industry must be able to understand other's cultural habitat, to develop intercultural sensitivity and to learn how to stand in the foreign colleagues' shoes. Hence, the choice of leaders must be taken carefully.

According to Lewis (2006), there are three culture categories: linear-active (task-oriented, highly organized planners), multi-active (people-oriented, loquacious interrelations) and reactive (introverted, respect-oriented listeners). Managers in linear-active cultures are usually task oriented, logic, focus on immediate achievements and results, orderly, well-planned, rely on facts and look for technical competence. Multi-active managers are more extroverted and emotional, networkingoriented, and rely on their ability to persuade people and use human force as an inspirational factor. Reactive culture managers display modesty and courtesy, paternalistic, equally people-oriented, but dominate with knowledge, patience and quiet control.

Linear-active people are generally motivated by achievement, globalization concept, access to high technology, and opportunity for individual flair. Multi-active people are motivated by words (emotion, compassion, understanding), and reactive people are motivated by collective goals and action, trust, integrity and saving one's face. Meanwhile, the perspective and concept of change, innovation and decision in those cultures are in Table 2. 
Table 2 Concept of Change, Innovation and Decision

\begin{tabular}{|c|c|c|c|}
\hline & Linear-Active & Multi-Active & Reactive \\
\hline Change & $\begin{array}{ll}\text { - } & \text { Necessary } \\
\text { - } & \text { Stimulates growth and } \\
& \text { improvement } \\
\text { - } & \text { Profit-oriented } \\
\text { - } & \text { Any change is better than } \\
& \text { no change }\end{array}$ & $\begin{array}{ll}\text { - } & \text { Exiting } \\
\text { - } & \text { Stimulation people } \\
\text { - } & \text { Relate to the company's social } \\
& \text { reputation } \\
\text { - } & \text { Usually benefits top management }\end{array}$ & $\begin{array}{ll}\text { - } & \text { Slowly and gradually } \\
\text { - } & \text { No need if everything is fine } \\
\text { - } & \text { Employment-oriented } \\
\text { - } & \text { It is often seen as something } \\
& \text { dangerous }\end{array}$ \\
\hline Innovation & $\begin{array}{l}\text { - } \quad \text { Something important } \\
\text { - } \quad \text { Comes from individual } \\
\text { - } \quad \text { Show support for others' } \\
\text { new ideas but voice any } \\
\text { doubts immediately }\end{array}$ & $\begin{array}{ll}\text { - } & \text { Should be aesthetic } \\
\text { - } & \text { Discovered in lengthy discussion } \\
\text { - } & \text { Imply you agree to others' ideas } \\
& \text { but modify or drop them later }\end{array}$ & 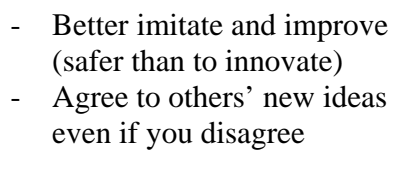 \\
\hline Decision & - Future oriented & - $\quad$ Bold and original & $\begin{array}{l}\text { - } \begin{array}{l}\text { Based on best past } \\
\text { precedents }\end{array}\end{array}$ \\
\hline
\end{tabular}

Source: Lewis (2006)

In Indonesia's hospitality industry, many expatriates come from France, Australia, Britain, USA, Switzerland, Spain, Singapore, Philippines, Malaysia, Japan, Germany, India and China. They have diverse values and different concepts of leadership and organization. Australian, British, American, Swiss, and Germany are categorized as linear-active cultures. The multi-active cultures are France and Spain. Singapore, Philippines, Malaysia, Japan, China and Indonesia are countries with reactive culture. India is between linear-active and multi-active cultures. From Lewis (2006), the concept of status, leadership, and organization, the motivating factors and what should be avoided from each country can be summarized as follows:

\section{Leadership and Status}

\section{Australia}

Australian managers must sit in the ring with the mates. They also are quick thinking and rapid decision making in business.

\section{Britain}

British managers are diplomatic, tactful, laid back, casual, reasonable, helpful, willing to compromise and fair. They regard meetings as occasions to seek agreement rather than to issue instructions. They are not sticklers to punctuality and like to completing task thoroughly. Managers usually want to be considered one the team but maintain a slight (power) distance. British managers generally achieve a balance between short and long term planning when creating strategies.

\section{China}

Harmony and Consensus are highly valued; confrontation is avoided. Respect for privacy. Bosses must be obeyed and the ideal bosses are respected autocrats. Age bring seniority. Privileges for managers are expected and popular. Punctual and do not like wasting time. Subordinates expect to be told what to do. Relationships are more important than tasks.

\section{France}

Autocratic management style. The boss often seems to have a roving style and patting subordinated on the back. French managers generally have wider horizons on the issues facing the company. High tolerance for management mistakes. Management is highly personalized (managers are to make many decisions on a daily basis). Paternalistic attitude (managers will show concern with their staff personal problems). 


\section{Germany}

Germans believe in the Ordnung Concept, where everything and everyone has a place in a grand design calculated to produce maximum efficiency. Clear chain of command in each department. Communication is vertical. Information and instructions are passed down from the top. The manager's status is based partly on achievement. Subordinates should be helped, advised and monitored, but once they understand, leave them alone to get on with it. Most Germans feel comfortable in a tight framework and they don't mind being told what they are expected to do. Germans like punctuality for an appointment or a meeting. Germans want detail and clarity. They work orderly.

\section{India}

The boss must be humanistic and initiate promotion for his subordinates. A strong work ethic is visible in Indian commerce. Indians expect warmth, respect and properness.

\section{Indonesia}

Leaders are generally paternalistic. Everything can be negotiable and takes time. Confrontation is avoided.

\section{Japan}

Ideas and suggestions are collected from lower level/ rank and file and decisions are made by consensus. Very punctual. Do not like to be rushed. Prefer teamwork and group decisions. Company's internal affairs should be conducted in a spirit of harmony and cooperation.

\section{Malaysia}

A good leader is religiously devout, sincere, humble and tactful. Status is inherited, not earned. They feel comfortable in a hierarchical structure.

\section{Philippines}

Managers often strive to do well and must give clear instruction to achieve progress. Expect queries from employees for help from the managers. Paternalism is common. Status is established by family name, connections and education.

\section{Singapore}

Comfortable with hierarchical structure. They value time and like punctuality.

\section{Spain}

Autocratic and charismatic leaders. They pride themselves on their personal influence on all their staff members, and they are able to persuade and inspire people. Spanish managers often see their decisions as irreversible.

\section{Switzerland}

Wealth is a common status symbol and it enhances power. They respect timetables and schedules. They do not like to waste time.

\section{USA}

American managers are assertive, aggressive, confident, goal and action oriented, optimistic, ready for change, vigorous, and hard worker. They value individual freedom. Leadership means getting things done, improving one's standard of living by making money for oneself, and making a profit for the firm and its shareholders. Status is based on achievement and wealth. Motivation is usually in term of monetary (bonuses, performance payments, profit-sharing and stock options). They like challenge, competition, quick and constant feedback, encouragement and praise. 


\section{Motivation}

Table 3 Motivating Factors and What to Avoid in Each Country

\begin{tabular}{|c|c|c|}
\hline Countries & Motivating Factors & What to Avoid \\
\hline Australia & $\begin{array}{l}\text { - The Key: Accept “mateship” } \\
\text { - Show you are willing to be one of the mates } \\
\text { - Always lead from the front and never ask } \\
\text { anyone to do anything you would not do } \\
\text { yourself } \\
\text { - Roll up your sleeves and help people to } \\
\text { move tables } \\
\text { - Sarcasm, irony, jokes and anecdotes are } \\
\text { popular } \\
\text { - Don't oversell yourself and undersell your } \\
\text { Australian host } \\
\text { - They are free spenders } \\
\text { - Like cheerfulness and affability } \\
\text { - Often mix business with social activities } \\
\text { - Do them favours, they are quick to repay } \\
\text { - Human rights are high on their priorities list }\end{array}$ & $\begin{array}{l}\text { - Using flowery speech } \\
\text { - Any form of arrogance } \\
\text { - Intruding into their } \\
\text { leisure time } \\
\text { - Boasting about your } \\
\text { past achievements } \\
\text { - Referring to their convict past }\end{array}$ \\
\hline Britain & $\begin{array}{l}\text { - The Key: At meeting, don't rock the boat } \\
\text { - Business and making money is a serious } \\
\text { matter, but try to look casual about it } \\
\text { - Be competitive, but don't tread openly on } \\
\text { others' toes } \\
\text { - Accept career challenge } \\
\text { - Statement and actions should be low key } \\
\text { - Do it obliquely when criticize, disagree or } \\
\text { praise } \\
\text { - Like orders to be given in the form of } \\
\text { suggestions and hints } \\
\text { - Accept ambiguities in discussion } \\
\text { - Put things in writing } \\
\text { - More interested in long-term relationships } \\
\text { than in quick deals } \\
\text { - Be prepared to accept some idiosyncratic or } \\
\text { even eccentric behavior } \\
\text { - Tell colleagues about yourself and family, } \\
\text { but don't reveal private details }\end{array}$ & $\begin{array}{l}\text { - Being sentimental, emotional and } \\
\text { openly critical in public } \\
\text { - Boasting about your connections } \\
\text { - Talking too much } \\
\text { - Taking sides in class questions } \\
\text { - Pushing logic too much } \\
\text { - Looking to serious or always taking } \\
\text { things literally } \\
\text { - Pressing them if they become vague }\end{array}$ \\
\hline China & $\begin{array}{l}\text { - The Key: Humility, Giving face } \\
\text { - Show compassion for Chinese difficulties } \\
\text { - Prepare well (they will appreciate it) } \\
\text { - Know Chinese history and praise their } \\
\text { inventiveness and artistic achievements } \\
\text { - Power distance is high and inequalities are } \\
\text { expected } \\
\text { - Tell subordinated what to do (kindly) } \\
\text { - Do not hesitate to be lavish when } \\
\text { entertaining } \\
\text { - Preserve harmony by saving face for } \\
\text { everybody on all occasions } \\
\text { - They consider themselves extremely } \\
\text { experiences and knowledgeable } \\
\text { - Show your reliability (they won't do business with people } \\
\text { they don’t trust) } \\
\text { - Learn to read between the line } \\
\text { - Gift-giving is an important feature in } \\
\text { business and social relationship } \\
\text { - The buyer comes first and expect added } \\
\text { respect } \\
\text { - Dress neatly and conservatively } \\
\text { - Close all meetings you control by thanking } \\
\text { everyone for attending }\end{array}$ & $\begin{array}{l}\text { - Showing anger or upset } \\
\text { - Rushing Chinese } \\
\text { business partners } \\
\text { - Boasting } \\
\text { - Rejecting a Chinese } \\
\text { proposal out of hand } \\
\text { - Ignoring anyone } \\
\text { brought into your } \\
\text { presence } \\
\text { - Topic of human rights (for Chinese) }\end{array}$ \\
\hline
\end{tabular}


Table 3 Motivating Factors and What to Avoid in Each Country (continued)

\begin{tabular}{|c|c|c|}
\hline Countries & Motivating Factors & What to Avoid \\
\hline France & $\begin{array}{l}\text { - The Key: Sharing visions, praising France } \\
\text { - Speak some French } \\
\text { - Be logical at all times but show flexibility } \\
\text { - Respect privacy and maintain formality } \\
\text { - Show the appreciation of the French's point of view } \\
\text { - They will respond quickly to your generosity } \\
\text { - They like to see things from every angle; be willing to } \\
\text { discuss topics and projects at great length } \\
\text { - Be imaginative, lively and use humor } \\
\text { - They are more relationship-oriented than deal-oriented }\end{array}$ & $\begin{array}{l}\text {-Expressing strong opinions until you } \\
\text { know their position } \\
\text { - They do not like prolonged silence } \\
\text { - Bottom-line focus, quick deals, } \\
\text { sarcasm and irony }\end{array}$ \\
\hline Germany & $\begin{array}{l}\text { - The Key: Indicating trust, demonstrating solidity } \\
\text { - Punctual, organized and efficient } \\
\text { - Every promise must be delivered } \\
\text { - Accept their criticism as being constructive } \\
\text { - Put many writing/ words; they like facts, figures, accurate } \\
\text { data/ information } \\
\text { - Give serious answers to serious questions } \\
\text { - Show trust and expect it from them } \\
\text { - They like consensus } \\
\text { - Say what you mean } \\
\text { - Respect privacy } \\
\text { - German friendship is deep }\end{array}$ & $\begin{array}{l}\text { - Displaying too much eccentricity } \\
\text { - Interrupting unfinished tasks } \\
\text { - Giving them too many tasks } \\
\text { simultaneously } \\
\text { - Overdoing small talks } \\
\text { - Gimmicks, slogans }\end{array}$ \\
\hline India & $\begin{array}{l}\text { - The Key: Don't talk to them; show sensitivity and } \\
\text { understanding } \\
\text { - Show respect and some knowledge of India's glorious } \\
\text { past } \\
\text { - Treat older people with great deference } \\
\text { - Tolerate ambiguity } \\
\text { - Look at things from their point of view } \\
\text { - Truth, facts and appearances are often subject to } \\
\text { negotiation }\end{array}$ & $\begin{array}{l}\text { - Taking sides between } \\
\text { Hindus and Muslims } \\
\text { - Humiliating them } \\
\text { - Discussing the caste } \\
\text { and Kashmir }\end{array}$ \\
\hline Indonesia & $\begin{array}{l}\text { - The Key: Show gentleness and respect } \\
\text { - Conformity is valued above individuality } \\
\text { - Show positive orientation toward work only if it is fun } \\
\text { - They often will ask you for advice and help when facing } \\
\text { difficulty } \\
\text { - You are expected to be clean, neat and well-dresses } \\
\text { - Small talk before doing business is expected } \\
\text { - Problems are referred in an indirect manner }\end{array}$ & $\begin{array}{l}\text { - Put pressure } \\
\text { - Being confrontational } \\
\text { - Getting involve in political issues }\end{array}$ \\
\hline Japan & $\begin{array}{l}\text { - The Key: Courtesy, giving face } \\
\text { - Be very polite at all times } \\
\text { - Entertain generously with splendid meals - which you } \\
\text { apologize afterwards } \\
\text { - Flatter them a lot } \\
\text { - Show great respect for their company } \\
\text { - They will take everything you say literally } \\
\text { - Never hurt their feelings } \\
\text { - Learn some Japanese, but don't overdo it } \\
\text { - When speaking English, speak slowly and distinctly } \\
\text { - They prefer oral agreements to written ones }\end{array}$ & $\begin{array}{l}\text { - Saying “No”, “It’s impossible” or } \\
\text { "we can’t” } \\
\text { - Making them lose face } \\
\text { - Trying to extract decisions at meetings } \\
\text { (pushy) }\end{array}$ \\
\hline Malaysia & $\begin{array}{l}\text { - The Key: Man is basically good } \\
\text { - Be courteous and gentle at all times } \\
\text { - Look always to the collective good } \\
\text { - Seek harmony and balanced discussion at meetings } \\
\text { - Problems are referred in an indirect manner and save face } \\
\text { for all } \\
\text { - Show that you posses dignity } \\
\text { - Compromise wisely }\end{array}$ & $\begin{array}{l}\text { - Roughness or loudness } \\
\text { - Direct criticism } \\
\text { - Pointing at people } \\
\text { - Focusing on the bottom line }\end{array}$ \\
\hline
\end{tabular}


Table 3 Motivating Factors and What to Avoid in Each Country (continued)

\begin{tabular}{|c|c|c|}
\hline Countries & Motivating Factors & What to Avoid \\
\hline Philippines & $\begin{array}{l}\text { - The Key: Make work pleasant } \\
\text { - Learn to read between the line } \\
\text { - Show your commitment to democracy and free trade } \\
\text { - Do business in their tempo and in the relax Filipino } \\
\text { manner and be flexible } \\
\text { - Dress neatly and maintain a professional manner } \\
\text { - Show great sympathy for their difficulties and offer help } \\
\text { - Take interest in their culture and language } \\
\text { - Make appropriate gifts to business colleagues }\end{array}$ & $\begin{array}{l}\text { - Being brusque } \\
\text { - Making someone lose face in public } \\
\text { - Making comments that is too direct }\end{array}$ \\
\hline Singapore & $\begin{array}{l}\text { - The Key: Showing efficiency and leanness } \\
\text { - Show efficiency and demonstrate frugality } \\
\text { - Try to think multi-culturally } \\
\text { - Praise the country's economic achievements } \\
\text { - Respect the elders and academic achievement } \\
\text { - Stay clean and well-dressed }\end{array}$ & $\begin{array}{l}\text { - Looking or sounding like an ex- } \\
\text { colonialist } \\
\text { - Discussing religion } \\
\text { - Criticizing too much on China }\end{array}$ \\
\hline Spain & $\begin{array}{l}\text { - The Key: Protect Spanish honor and integrity } \\
\text { - Emphasize on human relations (business should be } \\
\text { conducted on a person-to-person basis) } \\
\text { - Keep the dignity of man } \\
\text { - Accept physical closeness } \\
\text { - Hearty humor scores points } \\
\text { - Let them speak at length; do not oppose or interrupt. Win } \\
\text { their loyalty by listening well } \\
\text { - Spaniards “feel” situations rather than analyzing them } \\
\text { logically } \\
\text { - Show some knowledge of Spanish history, literature, art } \\
\text { - Influence them through personal appeal } \\
\text { - Do not rush, restrict or hinder them } \\
\text { - They have low legal consciousness }\end{array}$ & $\begin{array}{l}\text { - Paying too much attention to Spanish } \\
\text { ladies } \\
\text { - Referring to Spanish lack of } \\
\text { punctuality, slowness, political or } \\
\text { regional instability } \\
\text { - Allowing any Spaniard to lose face in } \\
\text { your presence }\end{array}$ \\
\hline Switzerland & $\begin{array}{l}\text { - The Key: Correctness and propriety } \\
\text { - Show you are dependable } \\
\text { - Be conformist and demonstrate frugality } \\
\text { - Acknowledge the high quality of Swiss products } \\
\text { - Address their worries and problems } \\
\text { - Indicate your financial solidity }\end{array}$ & $\begin{array}{l}\text { - Showing you are bored } \\
\text { - Breaking any laws, rules and } \\
\text { regulations } \\
\text { - Too much humor } \\
\text { - Eccentric behavior }\end{array}$ \\
\hline USA & $\begin{array}{l}\text { - The Key: Remuneration, new challenges } \\
\text { - Money } \\
\text { - Career challenges } \\
\text { - Use of humor } \\
\text { - Nothing is impossible in the US } \\
\text { - Be persistent in chasing results } \\
\text { - Link work and effort to return on investment } \\
\text { - Settle for the grand outline first; they are not willing to go } \\
\text { into details unless there is a deal } \\
\text { - They like simplification of issue } \\
\text { - Time is money } \\
\text { - They are nor afraid of taking risks } \\
\text { - They dislike protocol } \\
\text { - Accept sarcasm, irony and kidding } \\
\text { - They have a great work ethic } \\
\text { - Be innovative } \\
\text { - They are more interested in the future than in the past }\end{array}$ & $\begin{array}{l}\text { - Talking about problems openly } \\
\text { - Long silences } \\
\text { - Pulling rank } \\
\text { - Challenging the American dream }\end{array}$ \\
\hline
\end{tabular}

Source: Lewis (2006)

\section{Communication across Cultures}

Lewis (2006) also stated that the communication style of those countries are different. In Australia: they love criticizing themselves but take it poorly to being criticized; everyone is treated equally; Australian speak in a uniform language and there are hardly any regional variations; jokes, sarcasm, irony and anecdotes are popular; good sense of humor; they are used to informality. In 
Britain, the communication styles are charm, vagueness, humor, understatement; humor is regarded as one of the most effective weapons in business sessions, do it obliquely when you want to criticize, disagree or even praise.

In China, courteous but direct; mild flattery is appropriate; criticism is expresses indirectly. In France: they are suspicious of early friendliness in the discussion and dislike first names; removal of jackets and disclosure of personal and family details; they like a good, long discussion; they don't like to speak foreign language, they prefer to talk in French; they raise their voice when excited. In Germany, the communication styles are serious, open, frank, direct and often loud; they like to tell the truth; arguments are logical, weighty and thought out well; good listeners; They do not seek humor in a work context.

In India, Indian English is old-fashioned, flowery, verbose, excels in ambiguity; willing to listen at length, to develop a relationship; the key to get their attention is to be eloquent, humble and respectful. In Indonesia, conversations are conducted in quiet voice, without displaying emotions; deferential listening without interruption; rarely say anything that might be offensive; high desire to please; show no indication if they do not know about something; speak slowly and clearly when speaking in English, repeat if necessary. In Japan, language should be ambiguous, not blunt; Japanese do not like to report other people's statements since they are afraid if they report inaccurately it could result in embarrassment or injustice; they are good listeners; they are attentive and discipline audiences.

In Malaysia, tt is formal at first and gradually becoming informal; they do not like to interrupt; they are polite and respectful listeners; greetings are important. In Philippines, dialog-oriented communication style; oratory is valued and speeches can be lengthy; good and polite listeners, rarely interrupt. In Singapore, speech is courteous and by no means long-winded; careful listeners; do not interrupt but give good feedback at the end. In Spain, friendly and enthusiastic in small talk; they like physical and eye contact; they are touchy and sensitive. In Switzerland, polite conversationalist; they are not exciting speakers; they are good listeners; rarely interrupt and often taking notes. In USA, they use of humor whenever they can; they often get impatience and will say irritating things to get things moving; they are used to informality, first names, humor, persistence, and bluntness; they are fast talking; they respect honesty, straightforward, open disagreement, resilience and alertness; American English is irrevocably tough and blunt, compare then the modesty of British English.

\section{CONCLUSION}

The globalization of hospitality industry requires intercultural managers who are able to work in workforce diverse environment, as they are tasked with the responsibility of ensuring that communication between colleagues, clients and customers is clear, coherent and free from intercultural misunderstandings. Understanding different cultures will improve good relations between staff in the workplace and overcomes anti-discrimination. As a result, they can work in harmony, in order to provide better service to guests. To achieve this, hoteliers must possess certain key attributes; intercultural awareness, flexibility, and capitalizing on differences. Intercultural awareness is the fundamental foundation of all intercultural management skills. Managers need to understand how cultures affect human behavior in general, so that they can think and see beyond the box, in order to manage and communicate across cultures. 


\section{REFERENCES}

Brownell, J. (1991). Middle managers: facing the communication challenge. The Cornell Hotel \& Restaurant Administration Quarterly, Issue February, pp. 52-59.

Cichy, R. F., Sciarini, M. P., \& Patton, M. E. (1992). Food-service leadership: could Atilla run a restaurant? The Cornell Hotel \& Restaurant Administration Quarterly, Vol. 33, Issue. February, pp. 46-55.

Gudykunst, W. B. (1987). Cross-cultural comparisons. In C. Berger \& S. Chaffee (Eds.), Handbook of Communication Science. Beverly Hills, CA: Sage.

Hall, E. T. (1979). Beyond culture. New York: Anchor Press.

Hall, E. T., \& Hall, M. R. (1987). Hidden differences: doing business with the Japanese. New York: Anchor Press/Doubleday.

Hofstede, G., \& Bond, M. H. (1984). Hofstede’s culture dimensions: an independent validation using Rokeach’s value survey. Journal of Cross-Cultural Psychology, Issue. 15, pp. 417-433.

Hofstede, G. (1995). The business of international business is culture. In T. Jackson (Ed.). Crosscultural Management. Oxford, England: Butterworth Heinemann.

Kim, Y. Y., \& Reuben, B. D. (1988). Intercultural transformation: a systems theory. In Y. Y. Kim \& W. B. Gudykunst (Eds.), Theories in Intercultural Communication. Newbury Park, CA: Sage.

Kincaid, D. L. (1988). The convergence theory and intercultural communication. In Y. Y. Kim \& W. B. Gudykunst (Eds.), Theories in intercultural communication. Newbury Park: CA Sage.

Lewis, R. D (2006). When cultures collide. leading across cultures. Boston, MA: Nicholas Brealey International.

Powers, T. F., \& Riegel, C. D. (1993). A bright future for hospitality education: providing value in the 21st century. Hospitality Research Journal, Issue 17, pp. 295-308.

Samovar, L. A., \& Porter, R. E. (1995). Communication between cultures. Belmont, CA: Wadsworth.

Spitzberg, B., \& Cupach, W. (1984). Interpersonal communication competence. Beverly Hills, CA: Sage. 


\section{WRITERS' PROFILES}

Hera Oktadiana, with more than 10 years of experience in education field, currently holds a position as a Head of Hotel Management in BINUS University and Head of School of Hospitality and Tourism Management BINUS International. Previously she worked in Bunda Mulia Hospitality and Tourism Academy which is affiliated with the Regency Institute of TAFE South Australia as the Head of Hotel Management, Trisakti Tourism Institute as a lecturer and course coordinator, and then appointed as the Deputy Manager for International Hotel and Tourism Management program with IMI Switzerland. She was also involved in the Competency Based Training for Hotel and Restaurant Project, organized by AusAID and worked in Dutch and Japanese hospitality industry. She completed a dual degree master program (MM-MBA) from University of Bunda Mulia and Multimedia University (MMU) Malaysia. She was awarded a Bachelor degree from Trisakti Tourism Academy and a Certification from Hotel Management School Leeuwarden, the Netherlands. She has been involved in several associations such as Frontliners, SKAL International, PATA and HIKDIKTIPARI (Indonesia Tourism Higher Education Institution) as Chairman of International Relationship Division,

Rendy Herindra Djauhari, has 12 years of professional experiences in international education such as Program Coordinator of Education First, Head of Marketing and Public Relations Department of the Netherlands Education Center, and Country Director for an Australian International Education Market Research Company. He achieved a Master Degree in Communication Management from University Technology Sydney in 2005 through an Australian Development Scholarship and received a Postgraduate Diploma in Corporate Communication and Public Relations at London School of Public Relations and Bachelor in Facility Management from Saxion Universities of Applied Science in the Netherlands. 